\title{
Produksi Biodisel dari Minyak Jelantah Menggunakan Katalis Asam padat (Nafion/SiO $\left.{ }_{2}\right)$
}

\author{
Mahreni dan Tutik Muji Setyoningrum \\ Jurusan Teknik Kimia, Fakultas Teknologi Industri \\ Universitas Pembangunan Nasional "Veteran" Yogyakarta \\ Jln. Swk 104 Lingkar utara, Condongcatur, Yogyakarta, 55283. \\ Telp./Fax.: 0274486 889. Email: mahreni_03@yahoo.com
}

\begin{abstract}
Abstrak
Produksi biodisel dari minyak jelantah (Waste Cooking Oil, WCO) telah dilakukan menggunakan katalis ganda yaitu $\mathrm{Nafion} / \mathrm{SiO}_{2}$ sebagai katalis reaksi esterifikasi dan $\mathrm{NaOH}$ digunakan sebagai katalis transesterifikasi..Penelitian dilakukan melalui tiga tahap yaitu: sintesis katalis asam padat $\mathrm{Nafion} / \mathrm{SiO}_{2}$, sintesis biodisel menggunakan katalis tunggal $\mathrm{NaOH}$ dan sintesis biodisel menggunakan katalis $\left(\mathrm{Nafion} / \mathrm{SiO}_{2}\right.$ dan $\left.\mathrm{NaOH}\right)$. Katalis asam padat dibuat dari larutan Nafion 5\% berat ditambah dengan (Tetra Ethoxy Ortho Silicate, TEOS) menggunakan metode sol-gel fasa larutan menghasilkan katalis padat $\mathrm{Nafion} / \mathrm{SiO}_{2}$. Selanjutnya katalis padat $\mathrm{Nafion} / \mathrm{SiO}_{2}$ diaplikasikan sebagai katalis reaksi esterifikasi. Kondisi reaksi esterifikasi pada temperature $75^{\circ} \mathrm{C}$ dan waktu reaksi tetap 45 menit. Reaksi dijalankan di dalam labu leher tiga dilengkapi dengan pengaduk, temometer dan pendingin balik. Hasil reaksi dipisahkan dan lapisan atas digunakan sebagai reaktan reaksi transesterifikasi menggunakan katalis $\mathrm{NaOH}$ menghasilkan biodisel (FAME). Hasil analisis sifat fisika, yaitu viskositas, densitas dan titik nyala FAME yang dihasilkan sudah memenuhi standar persyaratan biodisel. Hasil karakterisasi secara kimia menunjukkan di dalam FAME terdapat lebih dari 6 macam metil ester menandakan bahwa FAME sudah terbentuk. Persentase biodisel yang dihasilkan dengan menggunakan katalis ganda lebih tinggi dibandingkan dengan menggunakan katalis tunggal membuktikan bahwa katalis asam padat mempunyai peranan penting dalam mengkonversi asam lemak bebas yang ada di dalam WCO.
\end{abstract}

\begin{abstract}
Production of biodisel from waste cooking oil (WCO) was performed using a double catalyst $\mathrm{Nafion} / \mathrm{SiO}_{2}$ as esterification catalyst and $\mathrm{NaOH}$ is used as transesterification catalyst. Study was conducted through three stages:as well as synthesis of Nafion $/ \mathrm{SiO}_{2}$ solid acid catalyst, the synthesis of biodisel using a single catalyst $(\mathrm{NaOH})$ and the synthesis of biodisel using a catalyst ( $\mathrm{Nafion} / \mathrm{SiO}_{2}$ and $\mathrm{NaOH}$ ). Solid acid catalyst is made of Nafion 5 wt.\% solution and the (Tetra Ethoxy Ortho silicate, TEOS) using solution phase sol-gel method to produce $\mathrm{Nafion} / \mathrm{SiO}_{2}$. Furthermore Nafion $/ \mathrm{SiO}_{2}$ was applied as esterification catalyst. Esterification reaction conditions at temperatures of $75^{\circ} \mathrm{C}$ and fixed reaction time of 45 minutes. The reaction is run at three-neck flask equipped with a stirrer, thermometer and cooling water. Products are separated and the upper layer is used as a reactant of transesterification reaction using $\mathrm{NaOH}$ catalyst and results biodisel (FAME). Result analysis of physical properties, ie viscosity, density and flash point FAME meets the standard requirements of biodisel. Chemical characterization in the FAME show there are more than six kinds of methyl esters indicate that FAME was formed. The percentage of biodisel that is produced by using dual catalyst is higher compared to using a single catalyst proved that the solid acid catalyst plays an important role in converting the free fatty acid in to ester in the WCO.
\end{abstract}

Keyword: solid acid, heterogeneous catalyst, $\mathrm{WCO}$, renewable energy, $\mathrm{Nafion} / \mathrm{SiO}_{2}$.

\section{Pendahuluan.}

Biodisel dari minyak sawit segar atau minyak non makanan seperti minyak jarak sudah biasa dilakukan melalui reaksi transesterifikasi trigliserida yang ada di dalam minyak atau lemak dengan alkohol rantai pendek dan bantuan katalis basa $(\mathrm{NaOH}, \mathrm{KOH}$ dan $\mathrm{Ca}(\mathrm{OH})_{2}$ ) (Phan \& Phan, 2008). Katalis basa lebih disukai dibandingkan dengan katalis asam karena reaksi lebih cepat dan temperatur reaksi lebih rendah. 
Biodisel dari jelantah (waste cooking oil, WCO) belum banyak diteliti karena beberapa hal. Hambatan yang pertama adalah masalah bahan baku. Untuk mendapatkan bahan baku dalam jumlah banyak dan kontinyu tidak mudah dan memerlukan biaya transportasi untuk mengumpulkan WCO dari restoran, pabrik makanan dan lain lain memerlukan biaya yang cukup mahal. Akan tetapi memanfaatkan WCO sebagai produk yang lebih bermanfaat merupakan usaha yang penting untuk mengurangi beban pencemaran lingkungan oleh minyak bekas. Minyak apabila dibuang ke badan air akan membentuk lapisan dipermukaan air menyebabkan oksigen dari udara tidak dapat mendifusi ke dalam air dan hal ini menyebabkan mahluk hidup dan biota lain yang ada di dalam air kekurangan oksigen (Zhang et al, 2003). Hambatan yang kedua adalah kandungan asam lemak bebas (free fatty acid, $F F A$ ) di dalam minyak jelantah lebih tinggi dibandingkan dengan FFA di dalam minyak segar. Biasanya kandungan FFA lebih besar dari $1 \%$ berat (Gui et al, 2008). Kandungan FFA dalam minyak sangat berpengaruh terhadap proses reaksi transesterifikasi minyak apabila menggunakan katalis basa. Karena FFA dalam minyak dan alkohol dengan adanya basa akan membentuk sabun (padat).

Campuran sabun, minyak dan alkohol ini membentuk emulsi yang dapat menghambat kecepatan reaksi transesterifikasi dan menimbulkan masalah pada proses pemisahan biodisel dan gliserol (hasil reaksi). Minyak goreng bekas (WCO) mengandung asam lemak bebas cukup tinggi biasanya $>1 \%$ berat (Patil et al, 2010). Asam lemak bebas ini dihasilan oleh hasil oksidasi dan hidrolisis minyak menjadi asam. Reaksi pembentukan asam semakin besar dengan pemanasan yang tinggi dan waktu yang lama selama penggorengan makanan. Asam lemak dapat menyumbat filter atau saringan dan menjadi korosi pada mesin diesel. Untuk menghilangkan FFA dari WCO, FFA harus dirubah menjadi ester dengan cara mereaksikan FFA dengan metanol menggunakan katalis asam (bukan basa), karena katalis basa dengan FFA dan methanol akan membentuk sabun. Produk biodisel harus dimurnikan dari produk samping, gliserin, sabun, sisa metanol dan soda. Sisa soda yang ada pada biodisel dapat menghidrolisa dan memecah biodisel menjadi FFA yang kemudian terlarut dalam biodisel itu sendiri. (http://id.wikipedia.org/wiki/Biodiesel). Pembentukan sabun juga dapat menghambat reaksi transesterifikasi trigliserida dengan alkohol karena sabun akan membentuk emulsi. Pembentukan emulsi juga akan menghambat pemisahan hasil reaksi FAME dan gliserol. Untuk mengatasi masalah tersebut, biodisel dari WCO harus dilakukan melalui dua tahap reaksi yaitu reaksi esterifikasi asam lemak bebas dengan alkohol menjadi ester menggunakan katalis asam dan tahap selanjutnya reaksi transesterifikasi menggunakan katalis NaOH. Selama ini reaksi esterifikasi menggunakan katalis asam sulfat atau asam klorisa (katalis homogen). Masalah menggunakan katalis homogen adalah sisa asam menyebabkan korosi peralatan dan asam (katalis) akan mencemari lingkungan. Asam padat adalah bahan padat bersifat asam seperti Nafion, SPEK, SPEEK, sering digunakan sebagai elektrolit padat di dalam sel elektrokimia. Nafion selama ini digunakan sebagai elektrolit pada sel bahan bakar hidrogen karena bersifat asam bronsted kuat. Rumus molekul Nafion $\left(\mathrm{C}_{7} \mathrm{HF}_{13} \mathrm{O}_{5} \mathrm{SC}_{2} \mathrm{~F}_{4}\right)$. Struktur Nafion dapat dilihat pada Gambar 1. (Mahreni, 2010).

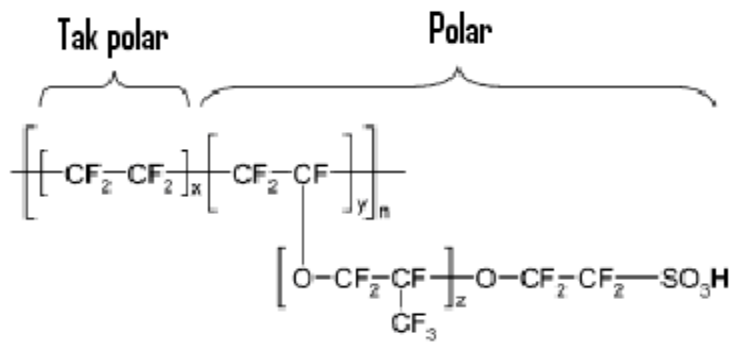

Gambar 1. Struktur Nafion.

Polimer Nafion terdiri dari rantai utama tetrafluoroethylene $\left(\mathrm{CF}_{2}-\mathrm{CF}_{2}\right)$ bersifat hidropobik dan rantai cabang perfluorosulfonic vinyl ether (PSVE) pada ujungnya mengikat gugus $\mathrm{SO}_{3} \mathrm{H}$ bersifat hidropilik dan bersifat konduktif terhadap proton. Dua sifat hidropobik dan hidropilik berada dalam satu molekul Nafion merupakan sifat yang unik karena Nafion 
mempunyai gugus hidropobik yang dapat mengikat

yang dapat mengikat alkohol sehingga kedua molekul ini akan teradsorbsi di permukaan Nafion dan terjadi reaksi antara FFA dan alkohol dipermukaan Nafion. Aktivitas katalisis Nafion dapat ditingkatkn dengan memperluas permukaan aktif Nafion dengan cara mendistribusikan molekul Nafion di permukaan $\mathrm{SiO}_{2} . \quad \mathrm{SiO}_{2}$ juga bersifat asam sehingga disamping berperan sebagai pendukung katalis (support) juga dapat meningkatkan keasaman katalis. Dalam penelitian uji aktifitas katalis dilakukan dengan mengaplikasikan $\mathrm{Nafion} / \mathrm{SiO}_{2}$ sebagai katalis reaksi esterifikasi FFA dengan metanol.

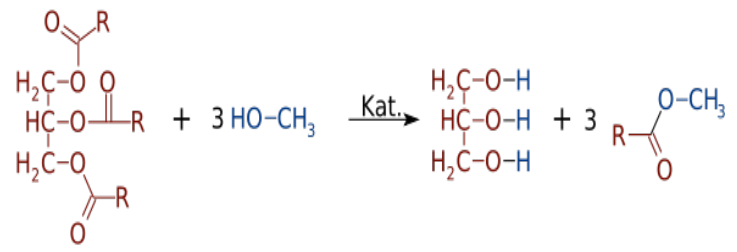

Gambar 2. Reaksi transesterifikasi minyak dengan alkohol menghasilkan metal ester dan gliserol. minyak dan juga mempunyai gugus hidropilik

Tabel 1. Spesifikasi sifat fisika biodisel dari minyak goreng segar, dari minyak goreng bekas (WCO) dan disel (fosil)

\begin{tabular}{|c|c|c|c|}
\hline Karakteristik & $\begin{array}{l}\begin{array}{l}\text { Biodisel dari minyak } \\
\text { segar }\end{array} \\
\end{array}$ & Biodisel dari WCO & Disel (fosil) \\
\hline $\begin{array}{l}\begin{array}{l}\text { Densitas } \\
\left(\mathrm{kg} / \mathrm{m}^{3}\right)\end{array} \\
\text { pada } \quad 40^{\circ} \mathrm{C}\end{array}$ & 870,6 & 876,08 & 807,3 \\
\hline $\begin{array}{l}\text { Specipic Gravity pada } \\
\text { suhu } 15,5^{\circ} \mathrm{C}\end{array}$ & 0,887 & 0,893 & 0,825 \\
\hline \multicolumn{4}{|l|}{ Suhu distilasi } \\
\hline $10 \%$ produk & 324 & 343 & 165 \\
\hline $50 \%$ produk & 335 & 345 & 265 \\
\hline $90 \%$ produk & 312 & 320 & 345 \\
\hline Flash Point $\left({ }^{\circ} \mathrm{C}\right)$ & 159 & 160 & 53 \\
\hline Fire Point $\left({ }^{\circ} \mathrm{C}\right)$ & 165 & 164 & 58 \\
\hline $\begin{array}{l}\text { Viskositas kenematik } \\
\text { pada }\left(40^{\circ} \mathrm{C}\right)\left(\mathrm{mm}^{2} / \mathrm{s}\right)\end{array}$ & 2,701 & 3,658 & 1,81 \\
\hline Nilai Kalor (kJ/kg) & 40120,78 & 39767,23 & 42347,94 \\
\hline API gravity & 27,83 & 26,87 & 39,51 \\
\hline Indek Cetan & 50,025 & 50,54 & 56,21 \\
\hline Anilin Point $\left({ }^{\circ} \mathrm{C}\right)$ & NA (tak ada data) & NA (tak ada data) & 77,5 \\
\hline
\end{tabular}

\section{Metodologi.}

.Dalam penelitian ini reaksi esterifikasi minyak jelantah dilakukan menggunakan katalis asam padat (Nafion/ $\mathrm{SiO}_{2}$ ) dengan tujuan agar pemisahan katalis dan biodisel dapat dilakukan dengan mudah dan tujuan kedua untuk meghemat biaya katalis karena katalis padat dapat diregenerasi (di daur ulang). Penelitian dilakukan melalui dua tahap yaitu tahap sintesis katalis padat $\left(\mathrm{Nafion} / \mathrm{SiO}_{2}\right)$ dan tahap kedua aplikasi katalis yang dihasilkan dalam reaksi esterifikasi minyak jelantah dengan memvariasikan ratio katalis/minyak dan ratio alkohol/minyak. Kwalitas biodisel yang dihasilkan dianalisis untuk mengtahui viskositas, densitas, dan titik nyala. Analisis secara kimia dilakukan menggunakan kromatrografi gas dengan tujuan menganalisis jenis dan kandungan metil ester di dalam biodisel. (Enweremadu \& Rutto, 2010). Hasil analisis dibandingkan dengan sifat fisika dan kimia biodisel dari minyak segar. Penelitian yang telah dilakukan oleh Enweremadu \& Rutto menggunakan katalis homogen ditampilkan oleh Tabell. 
2.1 Sintesis katalis asam padat $\left(\mathrm{Nafion} / \mathrm{SiO}_{2}\right)$.

Metode yang digunakan mengacu kepada metode sol-gel fasa larutan yang telah dilaporkan oleh (Mahreni et al, 2009). Bahan yang digunakan untuk sintesis $\mathrm{Nafion} / \mathrm{SiO}_{2}$ adalah larutan Nafion 5\% berat dalam pelarut Iso Propyl menghasilkan Nafion padat (penguapan dilakukan di dalam lemari asam pada suhu ruangan). Nafion padat dilarutkan kembali di dalam methanol sampai dengan konsentrasi Nafion sama dengan 5\% berat. Larutan Nafion-metanol ditambah dengan aquadest sehingga didapatkan perbandingan mol TEOS: etanol:air sama dengan 1:4:4. Selanjutnya campuran Nafion-etanol-air diaduk sampai membentuk gel. Pengadukan dihentikan ketika gel semakin memadat dan susah diaduk. Gel yang terbentuk tidak berwarna (tranparan) dikeringkan di dalam oven pada suhu $80^{\circ} \mathrm{C}$ untuk menguapkan sisa ethanol dan suhunya dinaikkan menjadi $120^{\circ} \mathrm{C}$ selama 2 jam, untuk menguapkan air da menghasilkan katalis asam padat $\left(\mathrm{Nafion} / \mathrm{SiO}_{2}\right)$.

\subsection{Aplikasi katalis asam padat $\left(\mathrm{Nafion} / \mathrm{SiO}_{2}\right)$ dalam reaksi esterifikasi minyak jelantah.}

Bahan yang digunakan adalah minyak jelantah yang sudah disaring dengan kertas saring whatman 41 . Metanol teknis (Merck), $\mathrm{NaOH}$, asam padat (Nafion/ $/ \mathrm{SiO}_{2}$ ). Minyak jelantah dicampur dengan metanol dan katalis asam padat dengan perbandingan mol divariasi. Larutan dimasukkan ke dalam labu leher tiga yang dilengkapi dengan pendingin balik dan termometer dan alat pengambil sampel. Larutan dipanaskan pada suhu $\left(75^{\circ} \mathrm{C}\right)$, diaduk selama 45 menit . Kemudian didinginkan dan larutan dibiarkan selama 24 jam sampai membentuk dua lapisan yang terpisah dengan jelas. Lapisan atas adalah metil ester (biodisel) dan lapisan bawah adalah gliserol dan katalis padat. Selanjutnya metil ester ditambah dengan metanol dan katalis basa $(\mathrm{NaOH})$ dengan perbandingan $\mathrm{NaOH} /$ minyak sama dengan $(0,7 \%$ berat). Perlakukan reaksi sama dengan reaksi esterifikasi. Setelah reaksi selesai larutan didinginkan dan dilakukan pemisahan biodisel dan gliserol. Selanjutnya biodisel dicuci dengan air panas beberapa kali untuk memisahkan katalis yang masih ada di dalam biodisel.

\subsection{Karakterisasi sifat fisika biodisel.}

Sifat fisika yang dianalisis meliputi viskositas, densitas dan titik nyala. Pengukuran viskositas biodisel menggunakan metode ASTM D 445-79. Pengukuran densitas menggunakan piknometer dan pengukuran titik nyala menggunakan metode ASTM D 92-78.

\subsection{Karakterisasi sifat kimia biodisel.}

Karakterisasi sifat kimia dilakukan menggunakan GC (Gas Chromatografi). Komponen yang diamati adalah komponen hasil reaksi esterifikasi dan reaksi
Alkohol (IPA). (DuPont), TEOS 96\% berat (Merck) dan etanol $96 \%$ berat (Merck). Bahan-bahan tersebut langsung digunakan tanpa pengolahan pendahuluan. Tahap pertama menguapkan pelarut Nafion (IPA) sehingga transesterifikasi yaitu metil ester. Analisis GC sangat penting dilakukan untuk membuktikan apakah katalis asam padat dapat berperan aktif sebagai katalis dalam reaksi esterifikasi asam lemak bebas (FFA) yang ada di dalam minyak jelantah menghasilkan ester. Keberadaan metil ester yang ada di dalam biodisel yang dihasilkan dapat menjadi indikator bahwa katalis asam padat dapat menggantikan peranan asam sulfat (katalis homogen).

\section{Hasil dan Pembahasan.}

\subsection{Hasil katalis asam padat $\mathrm{Nafion} / \mathrm{SiO}_{2}$.}

Perbandingan mol air/etanol/TEOS ditetapkan (4/4/1) dan berat Nafion divariasi dari 1-10 gram. Hasil penelitian sintesis asam padat menghasilkan material katalis transparan dengan perbandingan Nafion/TEOS dari $(0,03$ sampai dengan 0,15$)$. Katalis yang dihasilkan digunakan sebagai katalis reaksi esterifikasi dan persentase biodisel dengan perbandingan Nafion yang berbeda ditampilkan pada Gambar 3. Katalis yang dihasilkan semua berwarna transparan (tembus cahaya) berbentuk partikel. Berdasarkan hasil analisis bahan komposit menggunakan TEM (Transmitter Electron Mycroscope) yang dilaporan oleh (Mahreni et al, 2009) menyimpulkan bahwa struktur transparansi suatu bahan komposit berhubungan dengan kemampuan bahan meneruskan gelombang cahaya. Semakin bening suatu bahan kemampuan meneruskan cahaya semakin besar. Dismaping itu berhubungan juga dengan diameter partikel di dalam komposit. Semakin kecil diameter partikel suatu bahan komposit, kemampuan meneruskan cahaya pada panjang gelombang tertentu semakin besar ( $\%$ transmitansi semakin besar). Persen transmitansi Nafion murni terhadap sinar UV-vis (panjang gelombang antara $200-700 \mathrm{~nm}$ ) mendekati $95 \%$ dan komposit Nafion/ $/ \mathrm{SiO}_{2}$ dengan kandungan $\mathrm{SiO}_{2}$ sampai dengan 15\% mendekati $85 \%$ (Mahreni, 2009). Dalam penelitian ini sampel $\mathrm{Nafion} / \mathrm{SiO}_{2}$ tidak dianalisis menggunakan UV-Vis sehingga tidak dapat menentukan diameter partikelSiO ${ }_{2}$ yang ada di dalam matrik Nafion tetapi dapat disimpulkan bahwa struktur material komposit yang dihasilkan adalah homogen. Homogenitas katalis merupakan sifat yang sangat penting untuk menjamin kecepatan reaksi agar homogen. 


\subsection{Perolehan biodisel dengan variasi kandungan Nafion.}

Uji katalis dilakukan menggunakan minyak jelantah $(26,58 \mathrm{~g})$, berat metanol $(13,661 \mathrm{~g})$, waktu reaksi 45 menit dan temperatur rekasi $75^{\circ} \mathrm{C}$. Variasi kandungan Nafion di dalam katalis Nafion/TEOS dari $(0,03-0,15) \%$ berat. Gambar 3 menunjukkan semakin besar kandungan Nafion di dalam katalis padat, maka \% berat FAME (biodisel) yang dihasilkan semakin meningkat. Karena semakin besar kandungan Nafion di dalam katalis padat, komponen aktif semakin besar. Dalam katalis Nafion/ $\mathrm{SiO}_{2}$, peranan $\mathrm{SiO}_{2}$ adalah komponen pendukung sedangkan komponen aktif katalis adalah Nafion (Nafion bersifat asam kuat) sebagai donor proton dalam mekanisme reaksi esterifikasi FFA yang ada di dalam minyak dengan metanol. Oleh karena itu seperti yang ditampilkan oleh Gambar 3, persentase biodisel semakin besar dan mencapai $75 \%$ berat pada perbandingan Nafion/TEOS sama dengan 0,15 (berat/berat) dan perbandingan katalis/minyak (3\% berat). Dari gambar 3 juga disimpulkan bahwa dengan kenaikan Kandungan Nafion yang kecil dapat menaikkan persen hasil yang cukup signifikan, hal ini membuktikan bahwa metode solgel yang digunakan di dalam sintesis katalis $\mathrm{Nafion} / \mathrm{SiO}_{2}$ telah terbukti dapat menghasilkan komponen hibrid organik-anorganik yang homogen dan bersifat aktif katalisis. Untuk mengetahui seberapa besar persentase biodisel maksimal yang dapat dihasilkan maka penelitian perlu dilanjutkan dengan menambah kandungan Nafion di dalam katalis Nafion $/ \mathrm{SiO}_{2}$.

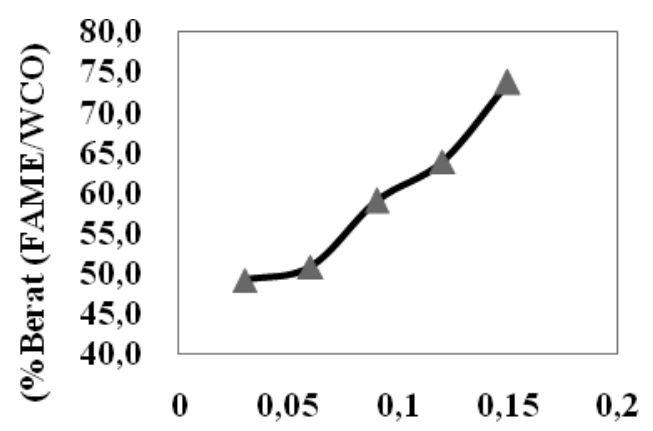

\section{Ratio (Nafion/TEOS) (berat/berat)}

Gambar 3. Hubungan produk biodisel (\% berat) dan konsentrasi Mafion dalam Nafion/TEOS.

\subsection{Variabel perbandingan $\mathrm{metanol} / \mathrm{minyak}$ terhadap persentase biodisel yang dihasilkan.}

Perolehan biodisel dari WCO tanpa menggunakan katalis asam padat dan dengan asam padat dapat dilihat pada Gambar 4 dibawah ini: Gambar tersebut menunjukkan bahwa semakin besar perbandingan mol methanol/minyak konversi semakin meningkat tanpa menggunakan asam padat dan dengan menggunakan asam padat. Peningkatan konversi ini disebabkan oleh karena kecepatan reaksi kekanan lebih cepat dibandingkan dengan kecepatan reaksi kekiri. Reaksi kekanan adalah reaksi transesterifikasi menghasilkan metil ester sedangkan reaksi keiri adalah reaksi peruraian metil ester menjadi alkohol dan minyak (trigliserida). Penomena ini dapat dijelaskan dengan houkum reaksi kesetimbangan. Untuk memperbesar konversi kesetimbangan, konsentrasi reaktan harus diperbesar atau dengan memisahkan salah satu hasi reaksi sehingga konsentrasi hasil reaksi kecil dan kecepatan reaksi kekiri menjadi lambat. Dalam penelitian ini hasil reaksi tidak langsung dipisajkan dan untuk menggeser agar reaksi kekanan lebih cepat dibandingkan kecepatan reaksi kekiri, maka konsentrasi reaktan dalam hal ini metanol harus diperbesar. Hal ini sesuai dengan laporan hasil penelitian sebelumnya yang telah dilakukan oleh beberapa peneliti (Gui et al, 2008).

Gambar 4 Perolehan biodisel dengan katalis ganda lebih tinggi dibandingkan dengan katalis tunggal disebabkan karena FFA di dalam minyak jelantah tidak terkonversi menjadi FAME tetapi menghasilkan sabun. Hal ini telah dibuktikan pada tahap awal reaksi menggunakan katalis basa (tunggal) menghasilkan hasil reaksi berbentuk padat dan untuk menghasilkan biodisel (cair) padatan dipanaskan dan di cuci sebelum reaksi transesterifikasi berlangsung. Hal ini tidak terjadi ketika menggunakan katalis ganda (tidak terbentuk sabun) selama reaksi esterifikasi dan transesterifikasi karena FFA yang ada di dalam jelantah telah bereaksi dengan alkohol dengan adanya katalis asam padat menjadi ester. FFA yang terkonversi menjadi ester menambah jumlah biodisel yang dihasilkan dengan menggunakan katalis ganda. Sifat kimia biodisel yang dihasilkan akan dilaporkan dengan detail pada makalah selanjutnya.

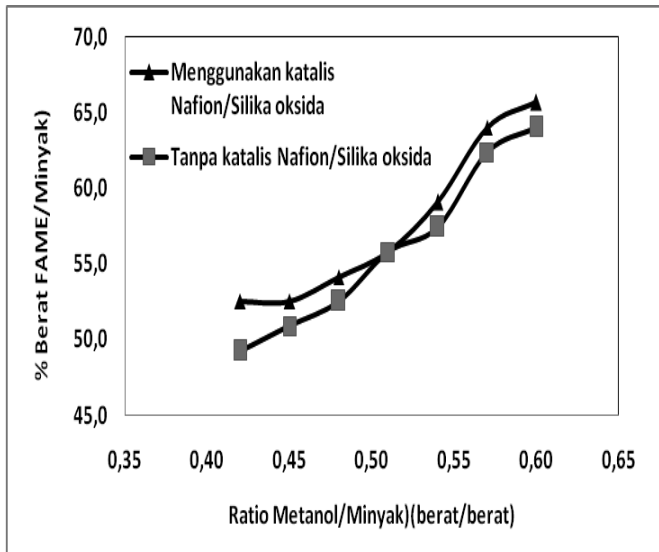


Gambar 4. Perbedaan \% Berat biodisel dengan menggunakan katalis ganda dan katalis tunggal dengan perbandingan Metanol/minyak yang divariasi.

\section{Kesimpulan}

Hasil sintesis asam padat dengan menggunakan metode sol-gel telah berhasil untuk menghasilkan katalis asam padat $\mathrm{Nafion} / \mathrm{SiO}_{2}$ dan aktivitas katalis telah diuji sebagai katalis reaksi esterifikasi FFA dalam jelantah (WCO). Hasil analisis sifat fisik biodisel dari minyak jelantan dengan menggunakan katalis ganda mendapatkan viskositas 4,49 cSt sudah sesuai dengan standar minyak disel (2,3-6 cSt), titik nyala biodisel yang dihasilkan $155^{\circ} \mathrm{C}$ lebih tinggi dibandingkan dengan titik nyala minyak disel (fosil) lihat tabel 1. Tetapi sesuai dengan titik nyala biodisel yang dihasilkan oleh peneliti sebelumnya diantara $165^{\circ} \mathrm{C}-164^{\circ} \mathrm{C}$. Katalis asam padat (Nafion $/ \mathrm{SiO}_{2}$ ) berperan sebagai katalis untuk reaksi esterifikasi FFA dalam minyak jelantah yang kurang-lebih $1 \%$ berat menjadi ester dan ester dari FFA ini dapat meningkatkan perolehan biodisel.

\section{Ucapan Terima kasih.}

Ucapan terima kasih untuk Angga dkk yang telah membantu dalam analisa di laboratorium..

\section{Daftar Pustaka.}

Anonim (http://id.wikipedia.org/wiki/Biodisel).

Anh N. Phan \& Tan M. Phan. 2008. Biodisel production from waste cooking oils. Journal of Fuel 87,3490-3496.

Enweremadu, C.C., Rutto, H.L. 2010. Combustion, emission and engine performance characteristics of used cooking oil biodisel-A review. Journal of Renewable and Sustainable Energy Reviews, 14, 2863-2873.

Gui, M.M., . Lee . K.T., Bhatia. S. 2008. Feasibility of edible oil vs. non-edible oil vs. waste edible oil asbiodisel feedstock. Journal of Energy 33,16461653.

Mahreni. 2010. Aplikasi membrane nanokomposit sebagai elektrolit sel bahan bakar hydrogen pada proton exchange membrane fuel cell. Jurnal Sain Materi Indonesia Vol. 13, No 1. hal. 52-58.

Nadir Dizge., Coskun Aydiner a., Derya Y. Imer., Mahmut Bayramoglu., Aziz Tanriseven., Bülent Keskinler. 2009. Biodisel production from sunflower, soybean, and waste cooking oils bytransesterification using lipase immobilized onto a novel microporous polymer. Journal of Bioresource Technology, 100, 1983-1991.

Zhang a, Y., Du_ M.A.,.McLean , D.D., Kates, M . 2003. Biodisel production from waste cooking oil: 2. Economic assessment and sensitivity analysis. Journal of Bioresource Technology, 90, 229-240.

Prafulla Patil., Shuguang Deng ., Isaac Rhodes ,J.,.Peter J. Lammers . 2010. Conversion of waste cooking oil to biodisel using ferric sulfate and supercritical methanol processes. Journal of Fuel $89,360-364$. 